\title{
Mechanism of action of the growth hormone secretagogue, L-692,585, on isolated porcine somatotropes
}

\author{
A Glavaski-Joksimovic ${ }^{1}$, K Jeftinija ${ }^{1}$, A Jeremic ${ }^{1}$, L L Anderson ${ }^{1,2}$ \\ and $\mathbf{S}$ Jeftinija ${ }^{\mathbf{1}}$
}

Neuroscience Program, Department of Biomedical Sciences, College of Veterinary Medicine, lowa State University, 1098 Veterinary Medicine Building, Ames,
lowa 50011, USA
${ }^{1}$ Department of Animal Science, lowa State University, Ames, lowa 50011, USA
(Requests for offprints should be addressed to S Jeftinija; Email: sjeftini@iastate.edu)

\begin{abstract}
The effects of a GH secretagogue, L-692,585 (L-585), and human $\mathrm{GH}$-releasing hormone $(\mathrm{hGHRH})$ on calcium transient and $\mathrm{GH}$ release were investigated in isolated porcine pituitary cells using calcium imaging and the reverse hemolytic plaque assay (RHPA). Somatotropes were functionally identified by the application of hGHRH. All cells that responded to hGHRH responded to L-585 application. Perfusion application of $10 \mu \mathrm{M}$ hGHRH and L-585 for 2 min resulted in an increase in intracellular calcium concentrations $\left(\left[\mathrm{Ca}^{2+}\right]_{\mathrm{i}}\right)$ of $53 \pm 1 \mathrm{nM} \quad($ mean \pm s.E.M. $) \quad(P<0 \cdot 01)$ and $68 \pm 2 \mathrm{nM}$ $(P<0 \cdot 01)$ respectively. The $\mathrm{L}-585$ response was characterized by an initial increase in $\left[\mathrm{Ca}^{2+}\right]_{\mathrm{i}}$ followed by a decline to a plateau level above the baseline. Concurrent calcium imaging with RHPA indicated that the L-585-evoked increase in $\left[\mathrm{Ca}^{2+}\right]_{i}$ coincided with $\mathrm{GH}$ release. L-585 significantly increased the percentage of plaque-forming cells $(24 \pm 3$ vs $40 \pm 6 \% ; P<0 \cdot 05)$ and mean area of plaques $\left(1892 \pm 177\right.$ vs $\left.3641 \pm 189 \mu^{2} ; P<0 \cdot 01\right)$ indicating increased GH release. Substance P (SP) analogue ([D-Arg ${ }^{1}, \quad$ D-Phe ${ }^{5}, \quad$ D-Trp $\left.\left.{ }^{7,11}\right]-S P\right)$ blocked, and the hGHRH receptor antagonist ((Phenylac-Tyr ${ }^{1}, \mathrm{D}-\mathrm{Arg}^{2}$, p-chloro-Phe ${ }^{6}$, Homoarg 9, Tyr $(\mathrm{Me})^{10}, \mathrm{Abu}^{15}, \mathrm{Nle}^{27}$,
\end{abstract}

D-Arg ${ }^{28}$, Homoarg ${ }^{29}$ )-GRF (1-29) amide) decreased the stimulatory effect of hGHRH. These failed to block the stimulatory effect of L-585, suggesting a different receptor for L-585 from the GHRH receptor. The hGHRHinduced calcium transients and initial peak increase induced by L- 585 were significantly decreased by removal of calcium from the bathing medium or the addition of nifedipine, an L-calcium channel blocker. The plateau component of L-585-induced calcium change was abolished by removal of calcium and nifedipine. These results suggest an involvement of calcium channels in $\mathrm{GH}$ release. Either SQ-22536, an adenylate cyclase inhibitor, or U73122, a phospholipase C (PLC) inhibitor, blocked the stimulatory effects of hGHRH and L-585 on $\left[\mathrm{Ca}^{2+}\right]_{i}$ transient, indicating the involvement of adenylate cyclasecAMP and PLC-inositol triphosphate pathways. These results further suggested that calcium mobilization from internal stores during the first phase of the L-585 response induced an increase in $\left[\mathrm{Ca}^{2+}\right]_{\mathrm{i}}$ whereas calcium influx during the second phase is a consequence of somatotrope depolarization.

Journal of Endocrinology (2002) 175, 625-636

\section{Introduction}

Growth hormone $(\mathrm{GH})$ secretion is controlled by hypothalamic stimulatory- and inhibitory-releasing hormones, GH-releasing hormone (GHRH) and GH releaseinhibiting hormone or somatostatin (SS). GH also participates in its own rhythmic secretion through feedback action on GHRH and SS neurons (Chan et al. 1996). Pulsatile GH secretion can be stimulated and amplified by novel compounds known as GH secretagogues (GHS) (Casanueva \& Dieguez 1999). The mechanism of the action of GHS is not fully established. GHS-elicited GH secretion involves both a direct effect and an indirect effect on the hypothalamus, suggesting that exogenous GHS may induce the release of another hypothalamic factor with GH-releasing capabilities (U-factor) (Bowers et al. 1991, Casanueva \& Dieguez 1999). Cloning of the human GHS receptor (Howard et al. 1996) and the isolation and characterization of an endogenous GHS, designated as ghrelin (Kojima et al. 1999), implicates GHS as a new physiological system in growth regulation by stimulating feeding and release of GH (Nakazato et al. 2001).

The GH-releasing peptides (GHRPs) were the first identified compounds in the class of GHS. Bowers et al. (1991) reported the discovery of a series of peptides derived from Leu- and Met-enkephalins that specifically 
released GH from the pituitary gland of humans and other animals. The biological action of GHRPs was considered different from GHRH. Benzolactam and spiroindolamine GHS have been developed with improved oral bioavailability and pharmacokinetic properties (Smith et al. 1993, 1997); L-692,429 was the first described non-peptidyl GHS (Smith et al. 1993). L-692,585 (L-585) is a nonpeptidyl GHS 10- to 20-fold more potent than L-692,429, as based on in vitro and in vivo studies and with no detectable change in receptor affinity (Jacks et al. 1994, Schoen et al. 1994). The GHS activity of L-585 has been reported in several species including beagles (Jacks et al. 1994), sheep (Guillaume et al. 1994) and swine (Hickey et al. 1996). In vivo experiments have shown that GHS in combination with GHRH augments GH release, and it is suggested that L-585 acts directly on somatotropes causing GH release (Smith et al. 1993). Besides direct effects on somatotropes, L-585 exerts central effects and requires an intact hypothalamic-pituitary axis for optimal GH release (Fairhhall et al. 1996, Hickey et al. 1996). Experiments in the pig in vivo have shown that L-585 also stimulates GH secretion by acting in combination with GHRH to interrupt the inhibitory tone of SS (Hickey et al. 1996).

The present studies have examined the signal transduction mechanism of the GHS, L-585, on calcium transient and $\mathrm{GH}$ release from isolated porcine somatotropes. An understanding of the molecular mechanisms by which GHS modulate GH secretion is of particular interest because of their biochemical simplicity and efficacy of oral administration.

\section{Materials and Methods}

\section{Chemicals}

Fetal bovine serum, horse serum (HS), minimum essential medium (MEM), Dulbecco's modified Eagle's medium (DMEM), Earle's balanced salt solutions (EBSS) and guinea pig complement were purchased from GibcoInvitrogen Co. (Carlsbad, CA, USA). HEPES, ethyleneglycol-bis-( $\beta$-aminoethyl ether) $\mathrm{N}, \mathrm{N}, \mathrm{N}^{\prime}, \mathrm{N}^{\prime}-$ tetraacetic acid (EGTA), papain solution, trypsin inhibitor, penicillin-streptomycin solution, poly-L-lysine, L-cysteine, L-glutamine, sodium pyruvate, bovine serum albumin (BSA), nifedipine, and staphylococcal protein-A were obtained from Sigma-Aldrich Co. (St Louis, MO, USA). Ovine red blood cells were purchased from Colorado Serum (Denver, CO, USA). Glucose, sodium bicarbonate $\left(\mathrm{NaHCO}_{3}\right)$, paraformaldehyde, and chromium chloride were obtained from Fisher Chemical (Fair Lawn, NJ, USA). Fura 2/AM and Pluronic F-127 were purchased from Molecular Probes (Eugene, OR, USA). The ABC kit was obtained from Vector Laboratories (Burlingame, CA, USA). U73211 and SQ-22536 were purchased from Biomol Research Laboratories (Plymouth Meeting, PA, USA). SS, SP analogue (D-Arg $\left.{ }^{1}, \mathrm{D}-\mathrm{Phe}^{5}, \mathrm{D}-\operatorname{Tr}^{7,11}\right)-\mathrm{SP}$, and GHRH antagonist (Phenylac-Tyr ${ }^{1}$, D-Arg ${ }^{2}$, p-chloro$\mathrm{Phe}^{6}$, Homoarg $^{9}, \mathrm{Tyr}(\mathrm{Me})^{10}, \mathrm{Abu}^{15}, \mathrm{Nle}^{27}, \mathrm{D}-\mathrm{Arg}^{28}$, Homoarg ${ }^{29}$ )-GRF (1-29) amide (human) were obtained from Bachem California, Inc. (Torrance, CA, USA). Human (h) GHRH and anti-porcine GH antibody were gifts from Dr A F Parlow, NIDDK National Hormone and Pituitary Program (Torrance, CA, USA). L-585 was a gift from Dr G J Hickey, Merck Research Laboratories, Rahway, NJ, USA.

\section{Experimental animals}

Yorkshire pigs, raised at the Iowa State University Animal Nutrition Farm, were used for these experiments. Animal care and experimental protocols were in accordance with the guidelines and approval of the Iowa State University Committee on Animal Care.

\section{Preparation of cell cultures}

Newborn pigs, 1-8 days of age, were killed with electrical shock and decapitated. Pituitary glands were immediately removed. The total number of animals used was 32 . The pituitary glands were collected in cold sterile EBSS solution $\left(4^{\circ} \mathrm{C}\right)$. Anterior lobes were transferred to a sterile cold $\left(4{ }^{\circ} \mathrm{C}\right) \mathrm{MEM}-0 \cdot 1 \%$ BSA medium. Primary cell cultures from neonatal anterior pituitary gland were established using a modified method of Huettner \& Baughman (1986). Tissues from two animals were incubated for $50 \mathrm{~min}$ at $37^{\circ} \mathrm{C}$ in $2 \mathrm{ml}$ EBSS-papain solution $(1.54 \mathrm{mg} /$ $\mathrm{ml})$. After incubation, the tissue was rinsed with EBSS solution and incubated for $5 \mathrm{~min}$ in trypsin-inhibitor solution $(1 \mathrm{mg} / \mathrm{ml})$. After being rinsed, once with EBSS solution and once with DMEM-0.1\% BSA medium, the tissue was mechanically dispersed in DMEM- $-0 \cdot 1 \%$ BSA medium by triturating through a fire-polished glass pipette. The undigested tissue was allowed to sediment. The supernatant containing cells was removed and filtered through a sterile filter. Cells were plated onto poly-Llysine $(0.1 \mathrm{mg} / \mathrm{ml} ; 100000 \mathrm{kDa})$-coated glass coverslips (at a density of $2 \times 10^{5}$ cells). Cells were allowed to attach to coverslips and, after 3-4 h, DMEM-0.1\% BSA medium was exchanged with DMEM medium supplemented with $10 \% \mathrm{HS}$ and $1 \mathrm{ml}$ penicillin-streptomycin solution per $100 \mathrm{ml}$ medium. Cultures were maintained at $37^{\circ} \mathrm{C}$ in a humidified 5\% $\mathrm{CO}_{2} / 95 \%$ air atmosphere. Experiments were carried out after 2 days in culture. The presence of somatotropes was confirmed by immunocytochemical methods.

\section{Immunocytochemistry staining}

After fixation with $4 \%$ paraformaldehyde for $30 \mathrm{~min}$ at room temperature, cells were incubated for $30 \mathrm{~min}$ in a $50 \%$ goat serum solution containing $1 \%$ BSA and $100 \mathrm{mM}$ L-lysine to block non-specific binding and $0 \cdot 4 \%$ Triton 
X-100 to permeabilize the membrane. To stain the somatotropes, cultures of anterior pituitary gland were incubated in polyclonal anti-porcine GH antibody (dilution 1:50 000). Antibody visualization was accomplished by using a Vectastain ABC kit (Vector) and the nickelenhanced 3,3' diaminobenzidine method (Jeftinija et al. 1992).

\section{Intracellular calcium imaging}

The effect of secretagogues on intracellular calcium concentration $\left[\mathrm{Ca}^{2+}\right]_{i}$ was evaluated by ratiometric imaging techniques (Parpura et al. 1994). Cells were loaded with Fura 2-AM for $40-60 \mathrm{~min}$ at $37^{\circ} \mathrm{C}$. One microliter of $25 \%(\mathrm{w} / \mathrm{w})$ of Pluronic F-127 was mixed with $4 \mathrm{nM}$ of AM ester to aid solubilization of the ester into aqueous medium. Coverslips containing pituitary cells were washed with HEPES-buffered solution and further incubated for $10 \mathrm{~min}$ at $37^{\circ} \mathrm{C}$ to allow de-esterification of Fura 2-AM. All image processing and analyses were performed using an Attofluour system (Atto Bioscience, Rockville, MD, USA) with a Zeiss microscope. Background subtraction and ratio images were used to calculate the $\left[\mathrm{Ca}^{2+}\right]_{\mathrm{i}}$ according to Equation 5 of Grynkiewitz et al. (1985). Using wavelengths of 340 and $380 \mathrm{~nm}$, Fura 2-AM was excited and the emitted light was collected at $520 \mathrm{~nm}$.

\section{Reverse hemolytic plaque assay (RHPA) for measurement of $\mathrm{GH}$ release in culture medium}

The RHPA was established according to the method of Taylor \& Clark (1994). Staphylococcal protein-A was coupled to ovine red blood cells using $0 \cdot 1 \% \mathrm{CrCl}_{3}$. After dissociation, pituitary cells were incubated for $48 \mathrm{~h}$ to allow them to recover biological responsiveness. After incubation, the cells were briefly exposed to trypsin ( $2.5 \mathrm{mg}$ trypsin in $10 \mathrm{ml}$ MEM-0.1\% BSA) to detach them from the culture dish. Following gentle triturating by a fire-polished glass pipette, the cells were separated by centrifugation $(1500 \mathrm{~g}$ for $10 \mathrm{~min}$ ), washed twice in MEM- $0 \cdot 1 \%$ BSA, and resuspended in DMEM-0.1\% BSA. The working cell dilution was $2.5 \times 10^{5}$ cells $/ \mathrm{ml}$. Equal amounts of the single secretory cell suspension and a $50 \%$ protein-A-labeled erythrocyte solution were mixed. The mixture was infused into Cunningham slide chambers and incubated at $37{ }^{\circ} \mathrm{C}$ in $95 \%$ air $/ 5 \% \mathrm{CO}_{2}$ for $50 \mathrm{~min}$. Pretreatment of the glass surface with poly-Llysine $(0.1 \mathrm{mg} / \mathrm{ml} ; 100000 \mathrm{kDa})$ ensured anchorage of the cells. After incubation, the chambers were rinsed with DMEM-0.1\% BSA. The monkey anti-porcine GH serum, diluted $1: 60$ in DMEM-0.1\% BSA, was then infused into the chambers alone or with L-585 (100 nM). The optimal incubation period was established by a preliminary study in which the maximum percentage of plaque-forming $\mathrm{GH}$ cells was achieved at $3 \mathrm{~h}$. Plaque formation was initiated by infusion of guinea pig

www.endocrinology.org complement in a final dilution of 1:40 in DMEM-0.1\% BSA, and the reaction was terminated after 50 min by the infusion of $1 \%$ solution of glutaraldehyde. Omission of any of the assay reagents, i.e. antiserum, complement, protein-A, resulted in failure to form a hemolytic plaque.

In every experiment, each treatment (with secretagogue or vehicle) was run in triplicate. Three separate experiments were performed. On each slide, the percentage of plaque-forming cells (\% PFC) was determined by counting the number of plaques among 200 pituitary cells. The mean plaque area (MPA) of 100 plaques/slide was measured by using a calibrated ocular reticule. The total secretion index, representing integrated hormone secretion per 100 pituitary cells, was calculated by multiplying the \% PFC and MPA (Goth et al. 1992, Mitani et al. 1996).

\section{Combination of RHPA and measurement of $\left[\mathrm{Ca}^{2+}\right]_{i}$}

A 1:1 mixture of protein-A-conjugated ovine red blood cells and pituitary cells was incubated for $1 \mathrm{~h}$ in Cunningham slide chambers, and then loaded with Fura 2-AM for $40 \mathrm{~min}$ at $37^{\circ} \mathrm{C}$. Fura $2-\mathrm{AM}$ was washed from the chamber with DMEM-0.1\% BSA. Twenty minutes later the presence of pituitary cells was confirmed under the fluorescent microscope. Calcium measurements were performed using consecutive excitation at 340 and $380 \mathrm{~nm}$. After recording a baseline of $\left[\mathrm{Ca}^{2+}\right]_{\mathrm{i}}$ for $60 \mathrm{~s}$, anti-porcine GH antibody and secretagogue $(10 \mu \mathrm{M}$ L-585) were both introduced into the chamber. Changes in $\left[\mathrm{Ca}^{2+}\right]_{i}$ were monitored for $15 \mathrm{~min}$. After recording, cells in the chambers remained on the microscope for $3 \mathrm{~h}$. Complement was introduced into the chamber, leading to lysis of red blood cells adjacent to GH-secreting pituitary cells. These plaques retrospectively identified the somatotropes.

\section{Statistical analysis}

Independent data are expressed as means \pm S.E.M. Simple comparisons between two groups were made by Student's $t$-test. Multiple comparisons were carried out by one-way analysis of variance followed by Tukey's multiple comparison test. Differences were considered as statistically significant at $P<0 \cdot 05$.

\section{Results}

Morphological identification of somatotropes in culture

Somatotropes in pituitary cell culture were confirmed by immunocytochemical staining. GH immunoreactive cells comprised $40 \%$ of the total pituitary cells in cultures. Somatotropes were approximately $10 \mu \mathrm{m}$ in diameter (Fig. 1A).

\section{Functional identification of somatotropes in culture}

Changes in the intracellular calcium concentration $\left(\Delta\left[\mathrm{Ca}^{2+}\right]_{\mathrm{i}}\right)$ mediate a variety of biological responses in both 
A

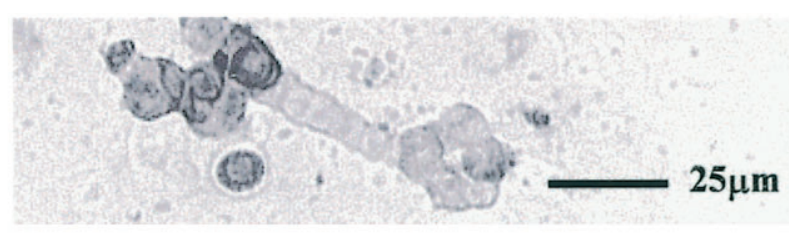

GH positive cells

B

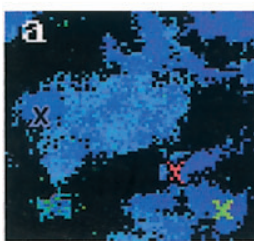

control

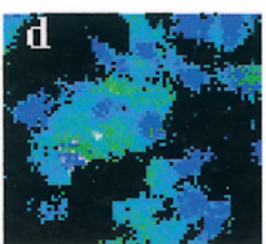

L-585

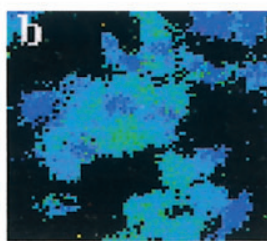

hGHRH

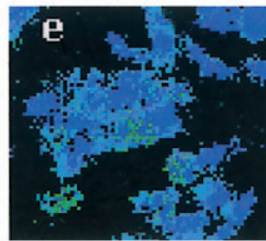

wash
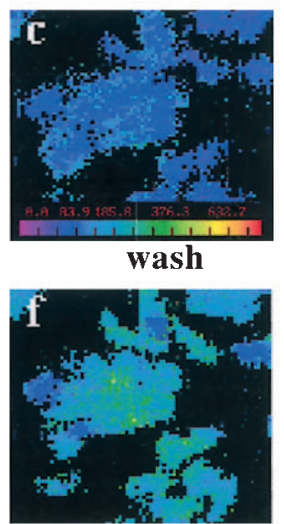

50 mM K

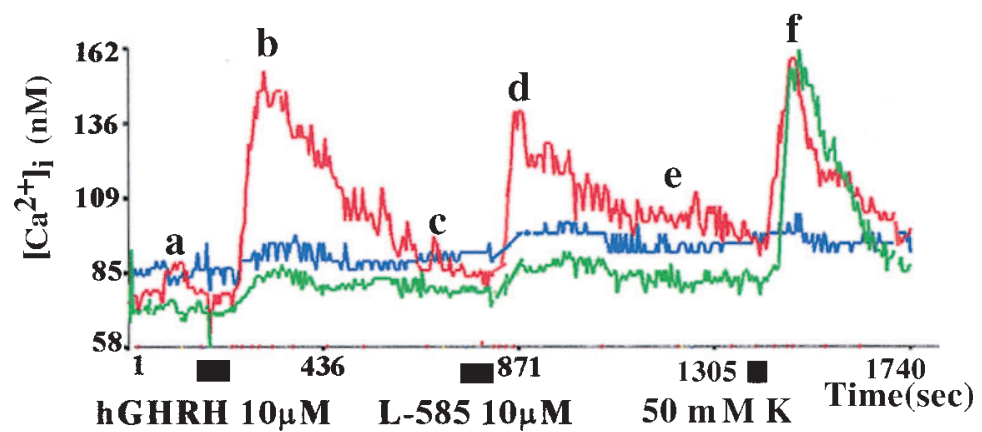

C

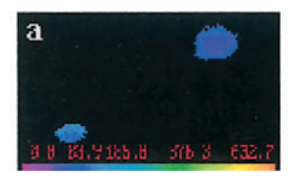

control

D

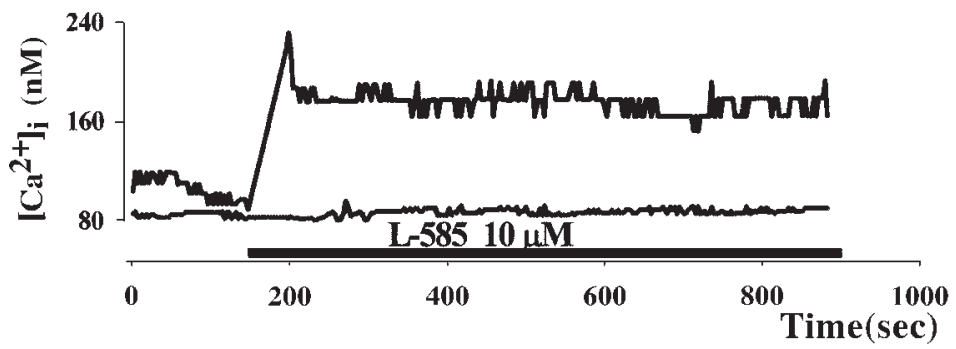


excitable and non-excitable cells. GH cells were functionally identified by a $\left[\mathrm{Ca}^{2+}\right]_{\mathrm{i}}$ increase above the baseline following hGHRH application. Perfusion with hGHRH $(10 \mu \mathrm{M})$ for $2 \mathrm{~min}$ significantly increased $\left[\mathrm{Ca}^{2+}\right]_{\mathrm{i}}$ by $53 \pm 1 \mathrm{nM}$ (means \pm S.E.M.; $n=578 ; P<0 \cdot 01$; Fig. $1 \mathrm{~B}$ ). Of the cells that responded to hGHRH, all $(100 \%)$ also responded to L-585, which was applied $10 \mathrm{~min}$ after the application of hGHRH. Perfusion with $10 \mu \mathrm{M}$ L-585 for 2 min produced a prompt transient increase in $\left[\mathrm{Ca}^{2+}\right]_{\mathrm{i}}$, followed by the sustained decline to a plateau above the basal level. The initial increase in intracellular calcium reached a peak of $68 \pm 2 \mathrm{nM}(n=578 ; P<0 \cdot 01)$ approximately $80 \mathrm{~s}$ after the onset of L-585 application (Fig. 1B). Potassium at a concentration of $50 \mathrm{mM}$, a non-selective stimulus, elevated $\left[\mathrm{Ca}^{2+}\right]_{\mathrm{i}}$ by $53 \pm 1 \mathrm{nM}(P<0 \cdot 01)$ in all cells that responded to hGHRH and L-585 (Fig. 1B). Some cells only responded to the (non-specific) stimulation with $50 \mathrm{mM} \mathrm{K}^{+}$whereas others failed to respond to any stimuli (Fig. 1B).

\section{L-585 induced release of GH in a dose-dependent manner}

To demonstrate that calcium transient in cultured pituitary cells after application of L-585 coincided with GH secretion, we performed experiments where RHPA and $\left[\mathrm{Ca}^{2+}\right]_{\mathrm{i}}$ measurements were done concurrently. Hemolytic plaques were formed only around cells that on calcium imaging responded to L-585, which identified them as $\mathrm{GH}$-secreting somatotropes (Fig. 1C).

Before quantitatively studying the effects of L-585 on GH release, preliminary experiments were performed in which the maximum effective dose (EDmax) of L-585 for $\mathrm{GH}$ secretion was determined. When incubated with $10 \mathrm{nM}, 100 \mathrm{nM}$, and $10 \mu \mathrm{M} \mathrm{L}-585$, cultured pig somatotropes dose-dependently released $\mathrm{GH}$ with the EDmax of $100 \mathrm{nM}$. Using RHPA, the \% PFC, and their MPA after $3 \mathrm{~h}$ incubation, were quantified. A total secretion index (TSI) was calculated by multiplying \% PFC and MPA. Under basal conditions, $\mathrm{GH}$ plaques were formed in $24 \pm 3 \%$ of the pituitary cells in culture obtained from newborn pigs. The similar \% PFC (about 30\%) under basal conditions was observed in experiments with rat somatotropes (Niimi et al. 1994, Mitani et al. 1996). The average size of the $\mathrm{GH}$ plaques in control cultures treated with vehicle was $1892 \pm 177 \mu \mathrm{m}^{2}$. Incubation with $100 \mathrm{nM}$ L-585 significantly increased the number and size of plaques. The fraction of somatotropes forming plaques was increased to $40 \pm 6 \%(P<0 \cdot 05$; Fig. $2 \mathrm{~A})$ and the MPA was 1.92 -fold greater than controls $\left(3641 \pm 189 \mu \mathrm{m}^{2}\right.$; $P<0 \cdot 01$; Fig. 2B). L-585 also caused a significant increase in TSI $\left(\times 10^{-2}\right)$ (vehicle $5 \pm 1$ vs $13 \pm 2 ; \quad P<0 \cdot 01$; Fig. 2C).

\section{The stimulatory effect of $h \mathrm{GHRH}$ and $\mathrm{L}-585$ is receptor mediated}

To study the nature of the GHS effect on somatotropes, ligands were applied in succession. The second application of $10 \mu \mathrm{M}$ hGHRH caused an increased $\left[\mathrm{Ca}^{2+}\right]_{\mathrm{i}}$ in $63 \%$ of the cells (60 of 96) that responded to the first application of hGHRH, and $59 \%$ of cells (57 of 96) that responded to the first application of $10 \mu \mathrm{M} \mathrm{L}-585$ responded to repeated application of L-585. A second application of $10 \mu \mathrm{M}$ hGHRH and $10 \mu \mathrm{M}$ L-585 did not have an additive effect on the increase in $\left[\mathrm{Ca}^{2+}\right]_{\mathrm{i}}(32 \pm 2$ vs $20 \pm 1 \mathrm{nM} ; 58 \pm 4$ vs $25 \pm 3$ nM; Fig. 3B). Similarly, simultaneous application of hGHRH and L-585 in a concentration of $10 \mu \mathrm{M}$ also did not have an additive effect on the increase of $\left[\mathrm{Ca}^{2+}\right]_{\mathrm{i}}$ ( $57 \pm 4 \mathrm{nM} ; n=77$; Fig. $3 \mathrm{C}$ ) but a sustained plateau phase of calcium increase was prolonged compared with either agonist alone. In parallel run controls, average increase in $\left[\mathrm{Ca}^{2+}\right]_{\mathrm{i}}$ after application of $10 \mu \mathrm{M}$ GHRH and $10 \mu \mathrm{M}$ $\mathrm{L}-585$ alone was $56 \pm 3 \mathrm{nM}$ and $66 \pm 5 \mathrm{nM}$ respectively $(n=74$; Fig. 3A).

To determine whether the effects of hGHRH and L-585 were receptor mediated we utilized a GHRHreceptor antagonist and an SP analogue with GHRH antagonistic properties. The application of $10 \mu \mathrm{M}$ GHRH-receptor antagonist (Phenylac-Tyr ${ }^{1}$, D-Arg ${ }^{2}$, p-chloro-Phe ${ }^{6}$, Homoarg ${ }^{9}, \mathrm{Tyr}(\mathrm{Me})^{10}, \mathrm{Abu}^{15}, \mathrm{Nle}^{27}$, D-Arg ${ }^{28}$, Homoarg ${ }^{29}$ )-GRF (1-29) amide (human) for $10 \mathrm{~min}$ significantly decreased the rise in $\left[\mathrm{Ca}^{2+}\right]_{\mathrm{i}}$ evoked by hGHRH compared with controls run in parallel (68 \pm 8 nM, $n=27$ vs $47 \pm 3 n M, n=68 ; P<0 \cdot 01$; Fig. 4 A and B). In contrast, the application of GHRH-receptor antagonist did not influence the stimulatory effect of L-585 $(80 \pm 11 \mathrm{nM}, n=27$ vs $80 \pm 8 \mathrm{nM}, n=70$; Fig. 4B). SP analogue $\left(\left[\mathrm{D}-\mathrm{Arg}^{1}, \mathrm{D}-\mathrm{Phe}^{5}, \mathrm{D}-\operatorname{Trp}^{7,11}\right]-\mathrm{SP}\right)$, at a concentration of $10 \mu \mathrm{M}$, blocked the stimulatory effect of hGHRH (53 $\pm 2 \mathrm{nM}, n=48$ vs $0 \mathrm{nM}, n=46)$ but it did not influence the stimulatory effect of L-585 (75 $\pm 4 \mathrm{nM}$, $n=48$ vs $71 \pm 4 n M, n=44$; Fig. 4C). These findings

\footnotetext{
Figure 1 Morphological and functional identification of cultured porcine somatotropes. (A) Cells stained with anti-GH antibody in cultured porcine pituitary cells. Magnification $40 \times$. (B) The sequence of color images and kinetics of the $\left[\mathrm{Ca}^{2+}\right]_{i}$ changes illustrate the response of isolated pituitary cells to application of $10 \mu \mathrm{M} \mathrm{hGHRH}, 10 \mu \mathrm{M} \mathrm{L}-585$ and $50 \mathrm{mM} \mathrm{K}$. The GH-secretory cells (red cross and red line in the time-course histogram) responded to the application of hGHRH, L-585, and $50 \mathrm{mM} \mathrm{K}$. The non-GH-secretory cells responded to non-specific stimulation of $50 \mathrm{mM} \mathrm{K}^{+}$(green cross and green line in the time-course histogram) and non-excitable cells (possible stellate cells) failed to respond to any of stimuli (blue cross and blue line in the time-course histogram). (C) Calcium transient induced by L-585 coincides with release of $\mathrm{GH}$. Bath application of L-585 induced calcium transient in one of two cells illustrated in (A) and (B) images and in the time-course histogram in (D). Phase contrast images in (C) illustrate formation of plaque only around the cell that responded with calcium transient to L-585 application in (B).
} 
A

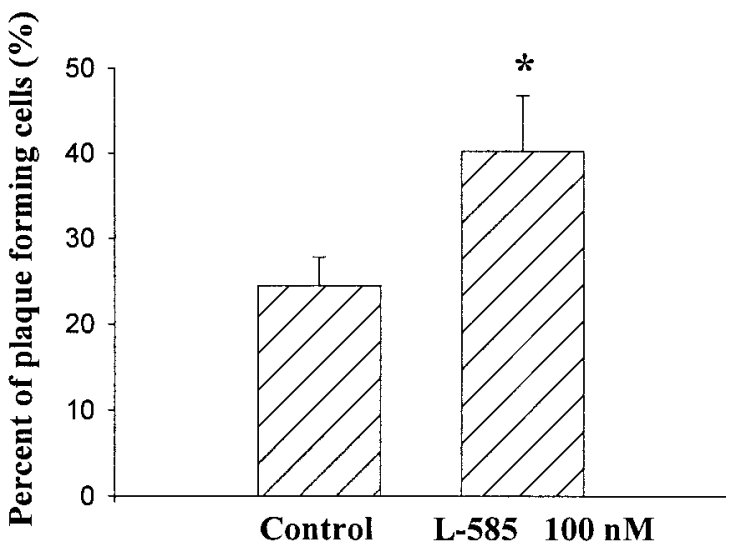

B

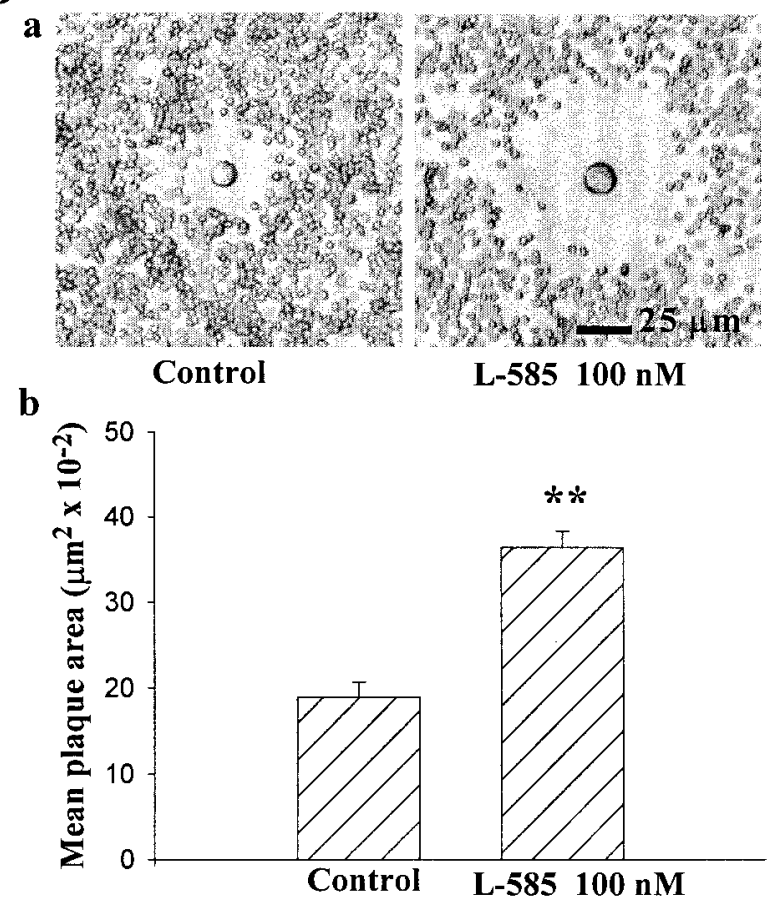

C

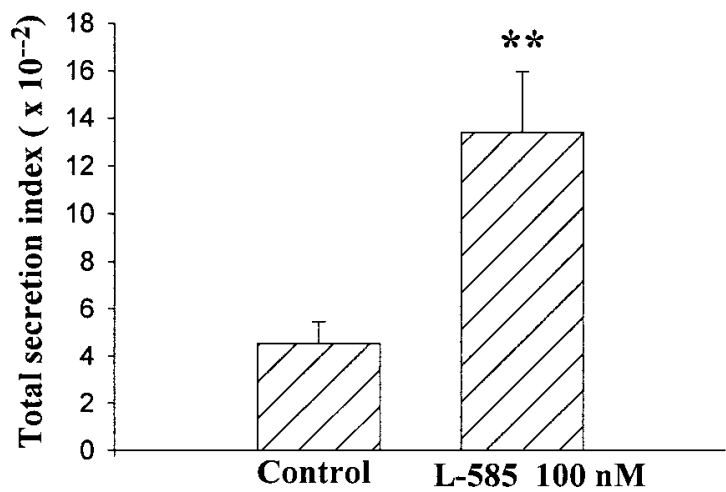

demonstrated that hGHRH and L-585 increase intracellular calcium concentration by acting through different receptors in cultured porcine somatotropes.

SS dose-dependently decreased the stimulatory effect of $h$ GHRH and L-585

Applications of SS at concentrations of 5 and $10 \mu \mathrm{M}$ decreased intracellular calcium levels by $15 \pm 2$ and $26 \pm 3 \mathrm{nM}$ respectively (Fig. 4D). The blocking effect of SS on the hGHRH- and L-585-evoked increase in $\left[\mathrm{Ca}^{2+}\right]_{\mathrm{i}}$ was dose dependent. Perfusion application of $10 \mu \mathrm{M}$ SS for $5 \mathrm{~min}$ before the application of $10 \mu \mathrm{M} \mathrm{hGHRH}$ and $10 \mu \mathrm{M} \mathrm{L}-585$ abolished the stimulatory effect of both agonists (Fig. 4D). After pretreatment of the cultures with $5 \mu \mathrm{M}$ SS for $5 \mathrm{~min}, 59 \%$ of cells (26 of 44 ) responded to $10 \mu \mathrm{M}$ hGHRH, and $57 \%$ of cells ( 25 of 44 ) responded to $10 \mu \mathrm{M}$ L-585, while in parallel run controls $94 \%$ of cells (47 of 50) responded to the application of the agonists. In the presence of $5 \mu \mathrm{M}$ SS, the increase in $\left[\mathrm{Ca}^{2+}\right]_{\mathrm{i}}$ evoked by hGHRH was significantly smaller compared with controls (44 \pm 3 vs $25 \pm 4 \mathrm{nM} ; P<0 \cdot 01$ ), while the peak increase of $\left[\mathrm{Ca}^{2+}\right]_{\mathrm{i}}$ produced by L-585 was not significantly decreased $(70 \pm 6$ vs $59 \pm 6 \mathrm{nM})$.

Role of membrane depolarization and calcium channels in the $h G H R H$ - and L-585-stimulatory effect

To investigate the role of extracellular calcium in hGHRH- and L-585-induced calcium transient in cultured somatotropes, cells were bathed in calcium-depleted HEPES with the addition of $1 \mathrm{mM}$ EGTA to yield an estimated free extracellular calcium level of $26 \mathrm{nM}$. We found that it was necessary to have some calcium in the bathing medium, otherwise cells detached from the culture substrate. Consistent with the ability of ligands to

Figure 2 Treatment with L-585 increases GH secretion from isolated porcine somatotropes determined by RHPA. (A) \% PFC in dispersed anterior pituitary cells when exposed for $3 \mathrm{~h}$ to vehicle (control) or $100 \mathrm{nM} \mathrm{L-585}$. The results are expressed as the mean \pm S.E.M. for three separate plaque assays. Two hundred pituitary cells were counted per assay $\left({ }^{*} P<0.05\right.$ vs vehicle). (B) The MPA of somatotropes in RHPA described in (A) are shown on phase contrast images (a) and as histograms (b). (a) Monolayers prepared from the same protein-A-labeled ovine erythrocytes (small cells) and somatotropes (large cells) derived from 2-day-old pigs. The cultures were treated with control medium and L-585 $100 \mathrm{nM}$. The cultures were incubated with $\mathrm{GH}$ antibody $(1: 60)$ for $3 \mathrm{~h}$, exposed to complement $(1: 40)$ for $50 \mathrm{~min}$, then fixed in $1 \%$ glutaraldehyde for $50 \mathrm{~min}$. Phase contrast images show the increase in size of plaques (pale areas in the monolayer of red blood cells) formed by somatotropes (oval cells in the center of each plaque) treated with L-585. (b) The MPA of somatotropes are expressed as the mean \pm S.E.M. of the MPA of 100 plaque-forming cells from three separate plaque assays ( ${ }^{*} P<0 \cdot 01$ vs vehicle). (C) The TSI of somatotropes in RHPA described in (A) is calculated by multiplying PFC and MPA $\left({ }^{* *} P<0 \cdot 01\right.$ vs vehicle). 
A

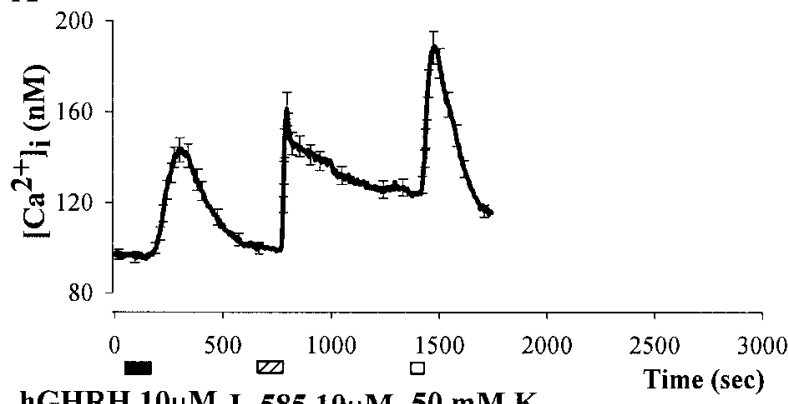

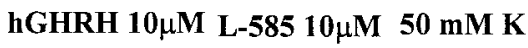

B

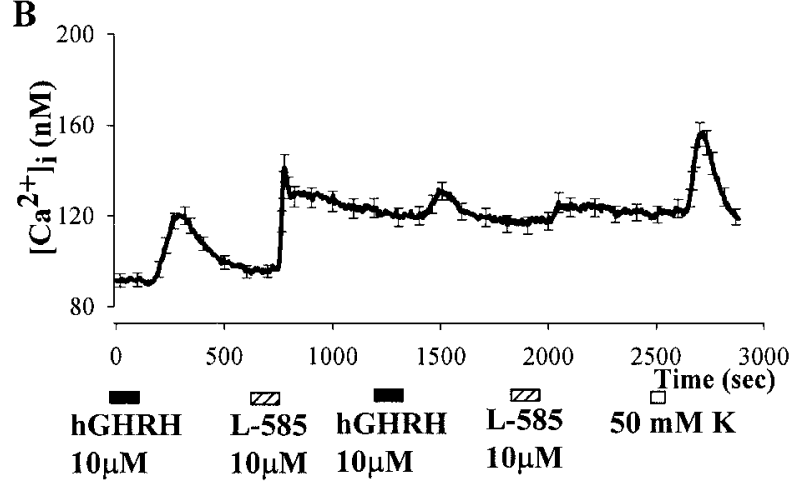

C

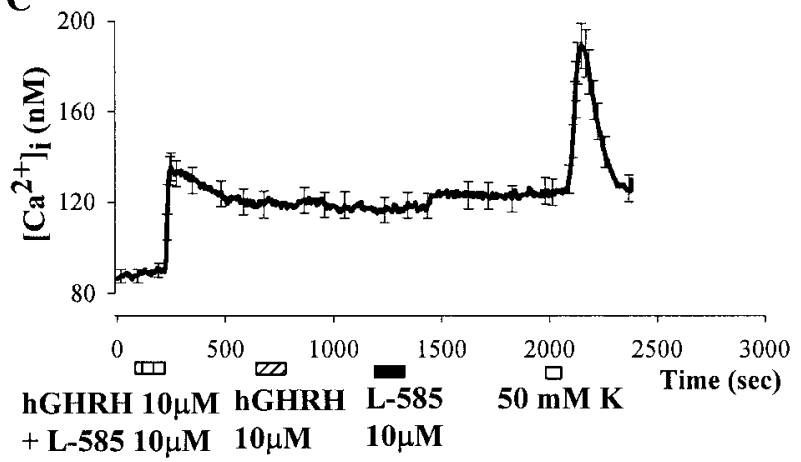

Figure $3 \mathrm{hGHRH}$ and L-585 induce calcium transient in isolated porcine somatotropes. (A) Increase in $\left[\mathrm{Ca}^{2+}\right]_{\mathrm{i}}$ after application of $10 \mu \mathrm{M} \mathrm{hGHRH}, 10 \mu \mathrm{M} \mathrm{L}-585$, and $50 \mathrm{mM} \mathrm{K}^{+}(n=51)$. (B) The second application of $10 \mu \mathrm{M}$ hGHRH and $10 \mu \mathrm{M} \mathrm{L}-585$ did not have an additive effect on the $\left[\mathrm{Ca}^{2+}\right]_{i}$ increase $(n=57)$. (C) Simultaneous application of $10 \mu \mathrm{M}$ hGHRH and $10 \mu \mathrm{M} \mathrm{L-585} \mathrm{did}$ not cause an additive effect on the increase in $\left[\mathrm{Ca}^{2+}\right]_{\mathrm{i}}(n=58)$.

activate calcium channels, the stimulatory effect of hGHRH and L-585 was significantly decreased in calcium-depleted saline (Fig. 5A and B). In parallel run control experiments in normal $\mathrm{Ca}^{2+}$ HEPES, $88 \%$ of cells (70 of 80) responded to $10 \mu \mathrm{M}$ hGHRH and L-585. Only $11 \%$ (9 of 81) of cells responded to $10 \mu \mathrm{M}$ hGHRH in low $\mathrm{Ca}^{2+}$ HEPES. The average increase of $\left[\mathrm{Ca}^{2+}\right]_{\mathrm{i}}$ was $22 \pm 7 \mathrm{nM}$, which is significantly less $(P<0 \cdot 05)$ than that evoked with hGHRH in normal $\mathrm{Ca}^{2+}$ HEPES (52 $\pm 4 \mathrm{nM}$ ). In contrast, $52 \%$ (42 from 81 ) of the cells responded to $10 \mu \mathrm{M}$ L-585 in low $\mathrm{Ca}^{2+}$ HEPES (Fig. 5B). The amplitude of L-585-evoked transient increase in $\left[\mathrm{Ca}^{2+}\right]_{\mathrm{i}}$ in low calcium HEPES was significantly smaller than in normal $\mathrm{Ca}^{2+}$ HEPES $(67 \pm 5$ vs $34 \pm 2 \mathrm{nM}$; $P<0 \cdot 01)$, and the second, sustained phase of calcium increase was almost abolished (Fig. 5B). These results suggested that extracellular calcium has an important role in the effect of hGHRH and L-585 on GH-secretory cells.

It has been demonstrated that GHRP-induced depolarization of somatotropes can activate voltage-dependent calcium channels and result in an increase of $\left[\mathrm{Ca}^{2+}\right]_{\mathrm{i}}$ (Herrington \& Hille 1994). To investigate the contribution of voltage-dependent $\mathrm{Ca}^{2+}$ channels in calcium influx evoked by hGHRH and L-585, experiments were performed in the presence of nifedipine, an antagonist of the L-type calcium channel. In control cultures, $10 \mu \mathrm{M}$ hGHRH and $10 \mu \mathrm{M}$ L-585 evoked a response in $94 \%$ of the cells (136 of 144). Application of $10 \mu \mathrm{M} \mathrm{hGHRH,} \mathrm{in}$ the presence of nifedipine, evoked a response in $88 \%$ of the cells (134 of 152) and $\mathrm{Ca}^{2+}$ transient in those cells was significantly decreased ( $55 \pm 2$ vs $25 \pm 1 \mathrm{nM} ; P<0 \cdot 01$; Fig. $5 \mathrm{C})$. In the presence of $10 \mu \mathrm{M}$ nifedipine, $91 \%$ of the cells (139 of 152) responded to $10 \mu \mathrm{M} \mathrm{L}-585$. The average increase in $\left[\mathrm{Ca}^{2+}\right]_{\mathrm{i}}$ was significantly smaller $(70 \pm 3 \mathrm{vs}$ $47 \pm 2 \mathrm{nM} ; P<0.01$; Fig. $5 \mathrm{C}$ ), and the duration of the sustained phase of calcium increase was brief.

To determine the role of $\mathrm{Na}^{+}$in hGHRH- and L-585-induced calcium transients, cultures were bathed in zero $\mathrm{Na}^{+}$solution (sodium was replaced with choline). Application of $10 \mu \mathrm{M}$ hGHRH in normal HEPES solution in parallel run control experiments evoked an increase in $\left[\mathrm{Ca}^{2+}\right]_{\mathrm{i}}$ in $92 \%$ of the cells (126 of 137). In zero $\mathrm{Na}^{+}$ HEPES, $71 \%$ of the cells (112 of 157) responded to $10 \mu \mathrm{M}$ hGHRH, and the average amplitude of calcium increase was $19 \pm 1 \mathrm{nM}$, a significantly smaller response compared with parallel run controls of $58 \pm 2 \mathrm{nM}(P<0 \cdot 01$; Fig. 5D). Similarly, $84 \%$ of the cells (132 of 157) responded to $10 \mu \mathrm{M} \mathrm{L}-585$ in zero $\mathrm{Na}^{+}$HEPES with $49 \pm 3 \mathrm{nM}$ increase in $\left[\mathrm{Ca}^{2+}\right]_{\mathrm{i}}$; the effect was significantly smaller compared with parallel run controls $(61 \pm 3 \mathrm{nM} ; P<0 \cdot 01$; Fig. 5D). In zero $\mathrm{Na}^{+}$HEPES, the effect of $50 \mathrm{mM} \mathrm{K}^{+}$on calcium transient was $40 \%$ of that recorded in normal HEPES (51 \pm 2 vs $21 \pm 1 \mathrm{nM} ; P<0 \cdot 01$; Fig. $5 \mathrm{D})$. These results further suggest an involvement of $\mathrm{Na}^{+}$-dependent depolarization in calcium transients induced by both hGHRH and L-585.

Signal transduction pathways, PLC, and adenylate cyclase-cyclic adenosine 3,5-monophosphate $(A C-c A M P)$ are activated by GH secretagogues

Results with the application of $\mathrm{L}-585$ in low $\mathrm{Ca}^{2+}$ solution suggest that in L-585-induced GH secretion, extracellular $\mathrm{Ca}^{2+}$ has an important role but that intracellular $\mathrm{Ca}^{2+}$ has some role too. The involvement of intracellular $\mathrm{Ca}^{2+}$ stores in hGHRH and L-585 action was further investigated in 
A

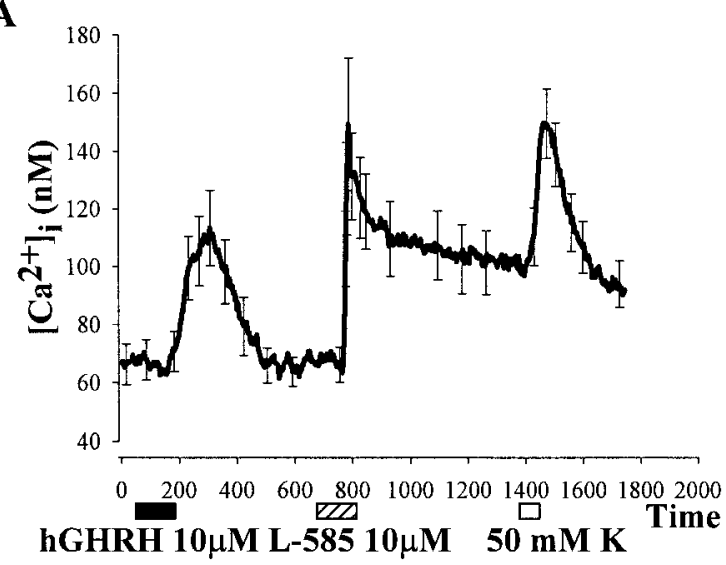

B

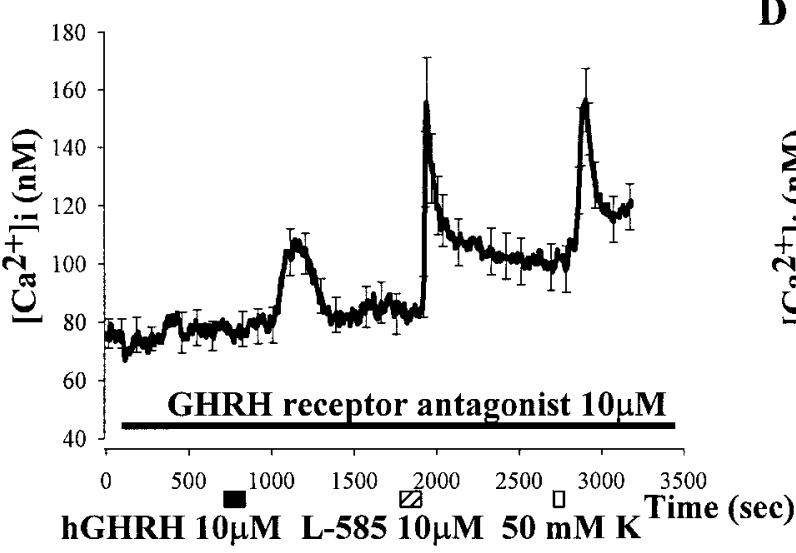

D
C

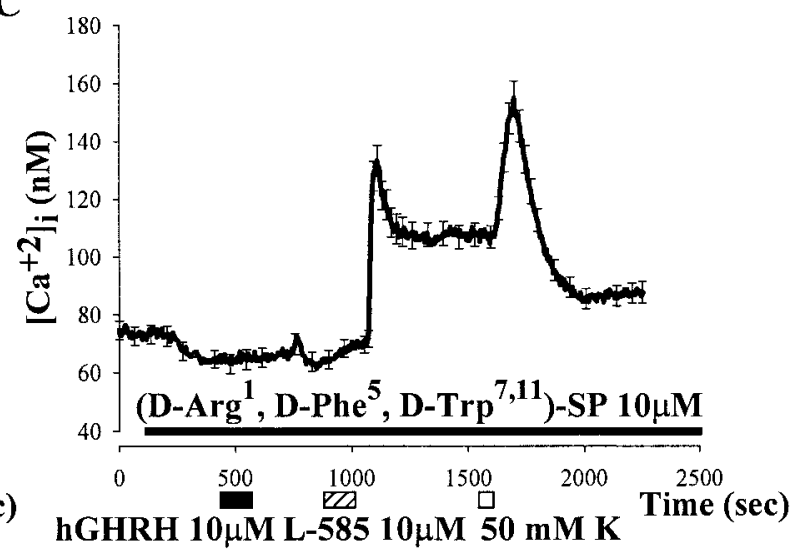

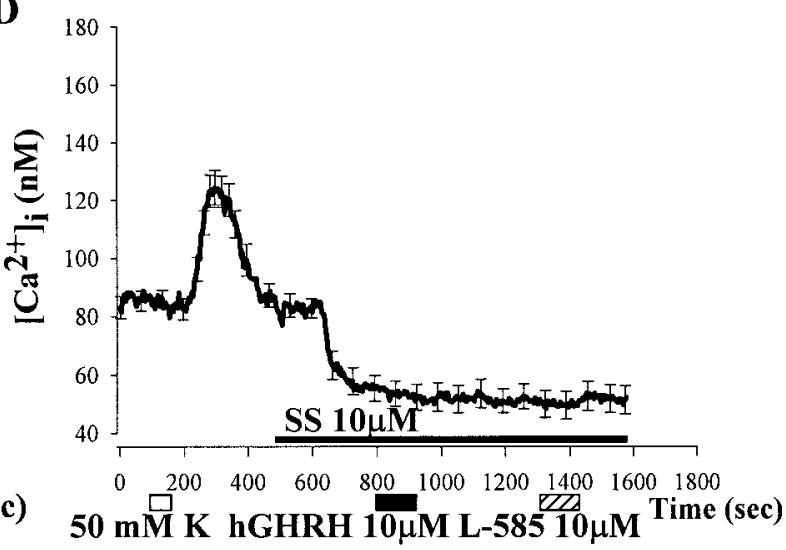

Figure $4 \mathrm{hGHRH}$ and L-585 increased $\left[\mathrm{Ca}^{2+}\right]_{\mathrm{i}}$ in isolated porcine somatotropes acting through different receptors. (A) Control effect of $10 \mu \mathrm{M} \mathrm{hGHRH}, 10 \mu \mathrm{M} \mathrm{L}-585$, and $50 \mathrm{mM} \mathrm{K}^{+}$on calcium transient in isolated porcine somatotropes $(n=21)$. (B) Application of GHRH receptor antagonist, Phenylac-Tyr ${ }^{1}, \mathrm{D}-\mathrm{Arg}^{2}, \mathrm{p}$-chloro-Phe $\left.{ }^{6}, \mathrm{Homoarg}^{9}, \mathrm{Tyr}(\mathrm{Me})^{10}, \mathrm{Abu}^{15}, \mathrm{Nle}^{27}, \mathrm{D}^{2} \mathrm{Arg}^{28}, \mathrm{Homoarg}^{29}\right)$-GRF (1-29) amide (human), decreased the stimulatory effect of $10 \mu \mathrm{M} \mathrm{hGHRH}$, while it had no influence on the L-585 effect ( $n=30$ ).

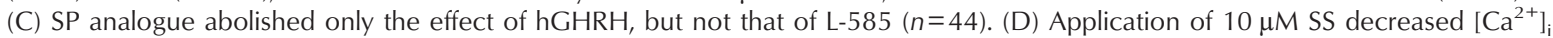
and blocked the stimulatory effect of hGHRH and L-585 $(n=10)$.

experiments with U73122, a selective inhibitor of PLC (Smith et al. 1990). Application of $10 \mu \mathrm{M} U 73122$ for 10 min significantly decreased the effect of hGHRH on calcium transient $(53 \pm 3 \mathrm{nM}, n=75$ vs $14 \pm 1 \mathrm{nM}$, $n=62 ; P<0 \cdot 01)$. Inhibition of PLC by $10 \mu \mathrm{M}$ U73122 also significantly reduced the effect of $\mathrm{L}-585(77 \pm 5 \mathrm{nM}$, $n=75$ vs $12 \pm 1 \mathrm{nM}, \quad n=110 ; \quad P<0 \cdot 01)$, implying an involvement of the PLC-inositol triphosphate $\left(\mathrm{IP}_{3}\right)$ pathway (Fig. 6).

It has been shown that GHRH activates the cyclic AMP pathway (Cheng et al. 1989). To determine whether L-585 activates this pathway, cell cultures were pretreated with SQ-22536, an adenylyl cyclase inhibitor (Tamaoki et al. 1993). SQ-22536 blocked the stimulatory effect of hGHRH and L-585 in a dose-dependent manner. After a 10-min application of SQ-22536 in concentrations of 50, 100 , and $200 \mu \mathrm{M}$, the amplitude of $\left[\mathrm{Ca}^{2+}\right]_{\mathrm{i}}$ increase evoked by $10 \mu \mathrm{M}$ hGHRH was decreased $51 \%(P<0 \cdot 01)$, $68 \%(P<0 \cdot 01)$, and $72 \%(P<0 \cdot 01)$ respectively (Fig. 7A).
Pretreatment with SQ-22536 at a concentration of $50 \mu \mathrm{M}$ decreased the stimulatory effect of L-585 to $41 \%$ $(P<0 \cdot 01)$, while SQ-22536 in concentrations of 100 and $200 \mu \mathrm{M}$ had a more prominent effect and decreased the stimulatory effect of L-585 to 55\% $(P<0 \cdot 01)$ (Fig. 7B).

\section{Discussion}

Porcine pituitary cells have a regulated secretory pathway utilized by secretory vesicles that fuse with the plasma membrane in response to a physiological stimulus such as GHRH or L-585 (Cho et al. 2002). Results from our experiments with simultaneous measurements of RHPA and calcium transients have shown that L-585 evoked an increase in $\left[\mathrm{Ca}^{2+}\right]_{i}$ that coincided with GH release. The amplitude of the $\left[\mathrm{Ca}^{2+}\right]_{\mathrm{i}}$ increase was greater after exposure to L-585 compared with hGHRH at the same micromolar concentration. $\mathrm{GH}$ secretion appears to be 


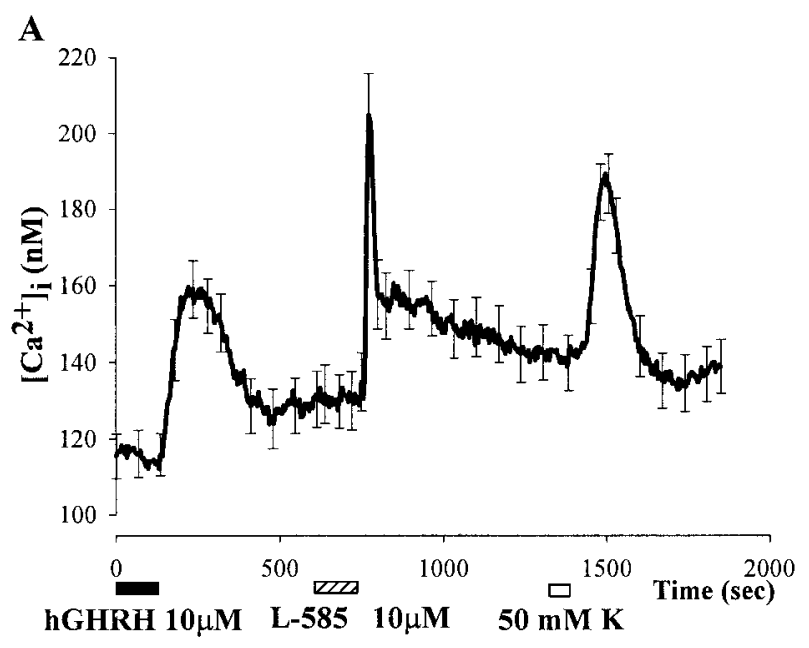

B

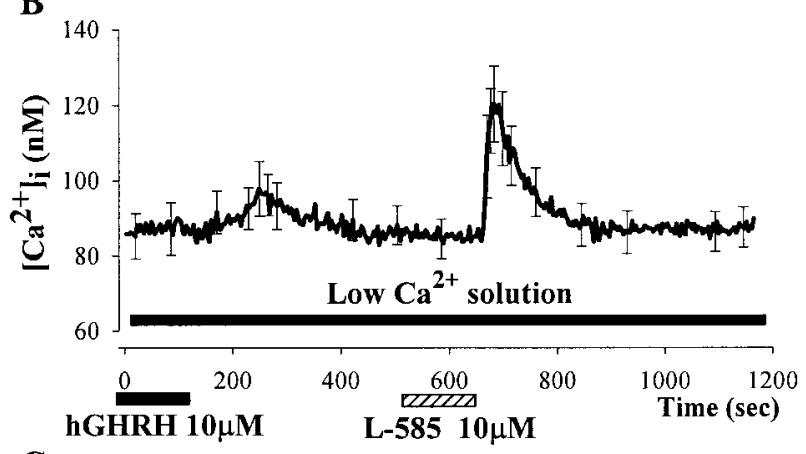

C
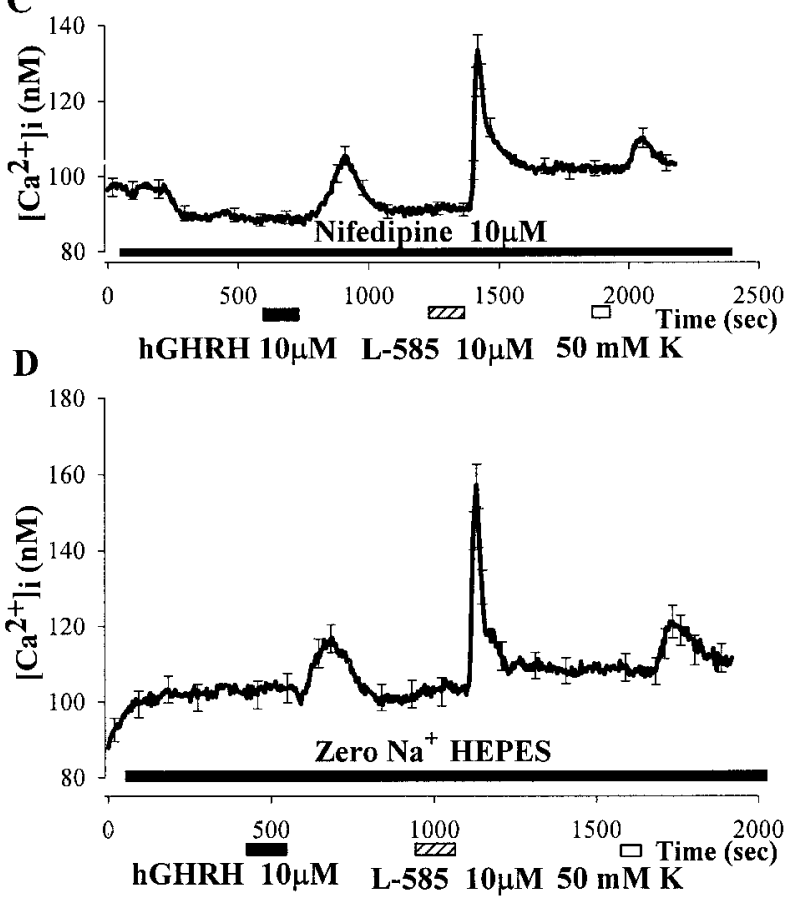

A

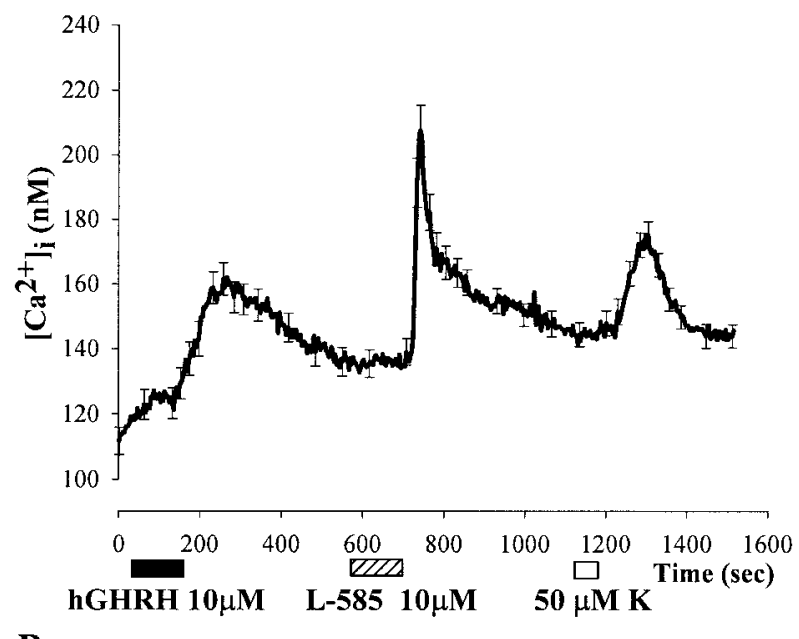

B

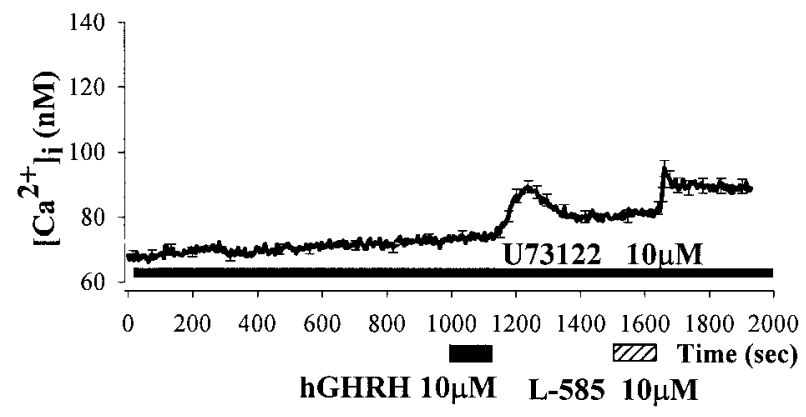

Figure $6 \mathrm{PLC}-\mathrm{IP}_{3}$ pathway is involved in the stimulatory effect of hGHRH and L-585 on cultured porcine somatotropes. (A) Control effect of $10 \mu \mathrm{M} \mathrm{hGHRH,} 10 \mu \mathrm{M} \mathrm{L-585}$, and $50 \mathrm{mM} \mathrm{K}^{+}$on calcium transient in isolated porcine somatotropes $(n=36)$. (B) Pretreatment of the cultured porcine pitutary cells with $10 \mu \mathrm{M}$ U73122 significantly decreased the stimulatory effect of hGHRH and L-585 $(P<0 \cdot 01 ; n=18)$.

directly related to intracellular free calcium concentration (Lussier et al. 1991a) and our calcium-imaging experiments indicate that L-585 was more potent than hGHRH in the rapid release of $\mathrm{GH}$. Our earlier in vivo experiments in the pig have shown that L-585 was more efficacious than GHRH in releasing significantly greater amounts of

Figure 5 Influx of calcium is involved in the hGHRH- and $\mathrm{L}-585$-induced calcium transient in isolated porcine somatotropes. (A) Control effect of $10 \mu \mathrm{M} \mathrm{hGHRH,} 10 \mu \mathrm{M} \mathrm{L}-585$, and $50 \mathrm{mM} \mathrm{K}^{+}$ on calcium transient in isolated porcine somatotropes $(n=40)$. (B) Depletion of $\mathrm{Ca}^{2+}$ from the bathing solution dramatically decreased the stimulatory effect of hGHRH and L-585 on isolated somatotropes $(n=5)$. (C) Perfusion of culture with $10 \mu \mathrm{M}$ nifedipine, a blocker of L-type Ca channels, significantly decreased the stimulatory effect of hGHRH, L-585, and $50 \mathrm{mM} \mathrm{K}^{+}$on isolated somatotropes $(n=70)$. (D) Removal of $\mathrm{Na}^{+}$ions from the bathing solution significantly decreased the effect of $10 \mu \mathrm{M}$ hGHRH, $10 \mu \mathrm{M} \mathrm{L-585}$, and $50 \mathrm{mM} \mathrm{K}^{+}$on calcium transient $(n=37)$. 
A

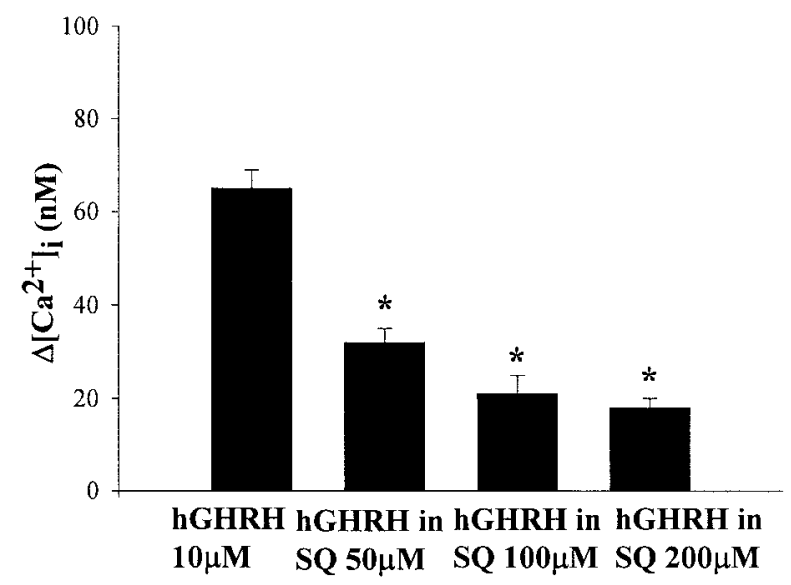

B

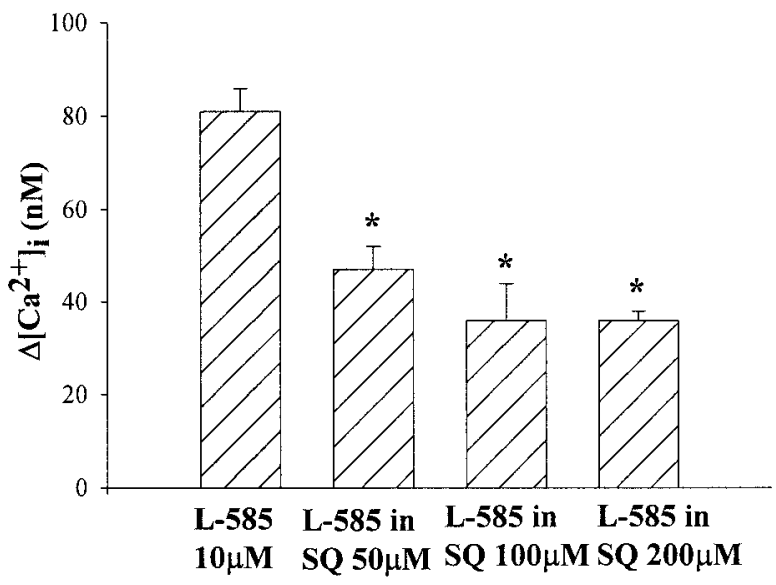

Figure 7 Application of SQ-22536 (SQ), an adenylyl cyclase inhibitor, dose dependently blocked the stimulatory effect of hGHRH and L-585. (A) Dose-dependent effect of SQ on $\mathrm{hGHRH}$-induced calcium transient in isolated porcine somatotropes $\left({ }^{*} P<0 \cdot 01\right.$ control $(\mathrm{hGHRH})$ vs $\left.\mathrm{hGHRH}+\mathrm{SQ}\right)$. (B) Dose-dependent effect of SQ on L-585-induced calcium transient in isolated porcine somatotropes $\left({ }^{\star} P<0 \cdot 01\right.$ control (L-585) vs L-585+SQ).

circulating GH (Hickey et al. 1996). These in vivo experiments also showed that GHRH and L-585 have a synergistic effect on GH secretion (Hickey et al. 1996). Simultaneous application of hGHRH and L-585 in the present study, however, did not have an additive effect on intracellular calcium concentration in cultured porcine somatotropes.

SS abolished the effect of hGHRH and L-585, but at a lower concentration it was more effective in suppressing the stimulatory effect of hGHRH compared with L-585. The effect of SS can be mediated by an inhibition of cAMP formation (Chen et al. 1996) or via decreased $\mathrm{Ca}^{2+}$ influx as a result of an increase in $\mathrm{K}^{+}$conductance and hyperpolarization of somatotropes (Lussier et al. 1991b). GHS depolarize the plasma membrane of somatotropes by inhibiting $\mathrm{K}^{+}$channels, and have been suggested to behave as functional antagonists of SS (Smith et al. 1997).

GHRH receptor antagonist and SP analogue with GHRH receptor antagonist properties did not influence the stimulatory effect of L-585, while they decreased and abolished the stimulatory effect of hGHRH on calcium transient, suggesting that L-585 and hGHRH act via different receptors on porcine somatotropes. Similarly, Smith et al. (1993) have shown that activity of L-692,429 can be blocked by both peptide and non-peptidyl antagonists of GHRP-6, but not by an antagonist of GHRH. Contrary to our results on cultured porcine somatotropes, the SP analogue in rats significantly reduced both GHRP-6- and L-692,429-stimulated GH response but had no effect in inhibiting the GHRH-stimulated GH response (Cheng et al. 1994).

The depletion of extracellular calcium greatly diminished but did not abolish the stimulatory effect of hGHRH and L-585 on porcine somatotropes. This suggests that both GHRH and L-585 mobilize $\mathrm{Ca}^{2+}$ from intracellular stores, but $\mathrm{Ca}^{2+}$ influx has a major contribution to calcium transient. In somatotropes, the major $\mathrm{Ca}^{2+}$ channels are the voltage-gated T- and L-types (Chen et al.1990). Perfusion of porcine cells with nifedipine significantly decreased the effect of hGHRH and L-585. This indicates an involvement of L-type $\mathrm{Ca}^{2+}$ channels in calcium influx induced by hGHRH and L-585, and that influx of calcium is a crucial step in the action of GHS.

The stimulatory effect of hGHRH and L-585 was greatly attenuated in a zero $\mathrm{Na}^{+}$environment, suggesting that both ligands can depolarize somatotropes, at least in part, through sodium channels. GHRH transiently increases $\mathrm{Na}^{+}$and $\mathrm{Ca}^{2+}$ current while it decreases membrane $\mathrm{K}^{+}$conductance, which leads to depolarization and an influx of extracellular $\mathrm{Ca}^{2+}$ (Chen et al. 1994). Potassium channels may also be involved in the action of L-585, because electrophysiology studies showed that peptidomimetics blocked $\mathrm{K}^{+}$currents in somatotropes, resulting in a depolarization and electrical spiking to enhance $\mathrm{Ca}^{2+}$ entry through voltage-gated channels (Smith et al. 1997). In our experiments, the increase in $\left[\mathrm{Ca}^{2+}\right]_{\mathrm{i}}$ after applying $\mathrm{K}^{+}$was significantly decreased by nifedipine and in sodium-free solution, indicating that calcium and sodium channels were involved in the depolarization of porcine somatotropes.

In this study, the few cells that responded to hGHRH in low calcium HEPES likely were low density (LD) cells. The first phase of L-585-evoked calcium increase resulted from intracellular $\mathrm{Ca}^{2+}$ mobilization, whereas the second phase represents calcium influx, because in low calcium HEPES, in nifedipine and in zero sodium HEPES, this second, sustained phase was almost abolished. In rats and pigs, it has been demonstrated that two morphologically and functionally distinct somatotrope subpopulations exist with LD and high density (HD) cells (Lindstrom \& Savendahl 1996, Ramirez et al. 1999). In pigs, blockade of 
$\mathrm{Ca}^{2+}$ influx with $\mathrm{CoCl}_{2}$ reduced the GHRH-stimulated GH secretion in both $\mathrm{LD}$ and HD somatotropes, while depletion of thapsigargin-sensitive intracellular calcium stores only decreased the secretory response to GHRH in LD cells (Ramirez et al. 1999).

Pretreatment of porcine somatotropes with SQ-22536, an adenylyl cyclase inhibitor, decreased the stimulatory effect of hGHRH and L-585 on calcium transient in a dose-dependent manner, implying that the binding of hGHRH and L-585 to their receptors activates adenylyl cyclase. GHRP-2 applied to ovine somatotropes dose dependently increased intracellular cAMP levels, whereas the GHRP-2-stimulated GH secretion was blocked by the inhibitor of adenylyl cyclase (MDL 12,330A) and by a cAMP-binding antagonist (Rp-cAMP). GHRP-2 did not increase cAMP levels in rat somatotropes, suggesting the existence of several subtypes of GHS receptor that are variably expressed in different species (Wu et al. 1996).

In our experiments, U73122, a PLC inhibitor, decreased the effect of hGHRH on calcium transient, indicating the involvement of the $\mathrm{PLC} / \mathrm{IP}_{3}$ pathway in the hGHRH action on porcine somatotropes. Ramirez et al. (1999) demonstrated that the adenylyl cyclase inhibitior (MDL-12,330A) abolished GHRH-stimulated GH release in both LD and HD subpopulations of porcine somatotropes, whereas U73122 only partially reduced this effect in LD cells. In the present investigation, U73122 decreased the transient increase in $\left[\mathrm{Ca}^{2+}\right]_{i}$ evoked by $\mathrm{L}-585$. Consistent with activation of this pathway were the observations that GHRP-6 and non-peptidergic GHS increased phosphoinositide turnover, and caused translocation of protein kinase C (Adams et al. 1995, Mau et al. 1995). The activation and interplay of several pathways of signal transduction mediate the effect of GHS in mobilizing $\mathrm{Ca}^{2+}$, cAMP, protein kinase $\mathrm{A}$ and $\mathrm{C}$, and phospholipase C (Smith et al. 1997, Muller et al. 1999).

In summary, L-585 in porcine somatotropes activates adenylyl cyclase and PLC pathways, suggesting that it may act through different receptors that are coupled to $G_{s}$ and $\mathrm{G}_{\mathrm{q}}$. Activation of these different signal transduction pathways mobilize calcium from internal stores during the first phase of the L-585-induced increase in $\left[\mathrm{Ca}^{2+}\right]_{\mathrm{i}}$. A second prolonged phase due to calcium influx results from somatotrope depolarization by $\mathrm{L}-585$ acting on $\mathrm{Na}^{+}$and $\mathrm{K}^{+}$ channels, and the activation of calcium channels through different second messengers. RHPA of cultured porcine somatotropes confirmed a connection between the L-585evoked mobilization of calcium and GH release.

\section{Acknowledgements}

We thank Dr A F Parlow for the hGHRH and antiporcine GH antibody, Dr G J Hickey for L-692,585 and Dr C G Scanes (Department of Animal Science, Iowa State University, Ames, Iowa, USA) for helpful com- ments. This work was supported in part by grants from The National Pork Producers Council, Des Moines, Iowa, The Iowa Pork Producers Association, Des Moines, Iowa, the USDA, Healthy Livestock Initiative Grants Program, and USDA. All experiments were performed following standards established by the Animal Welfare Act and NIH Guide for the Care and Use of Laboratory Animals, Publication 85-23. This is J-19515 of the Iowa Agriculture and Home Economics Experiment Station, Ames, Iowa (Projects 3901 and 2273, the latter contributing project to North Central Regional Research Project NC-113) and supported by Hatch Act and State of Iowa funds.

\section{References}

Adams EF, Petersen B, Lei T, Buchfelder M \& Fahlbusch R 1995 The growth hormone secretagogue, L-692,429, induces phosphatidylinositol hydrolysis and hormone secretion by human pituitary tumors. Biochemical and Biophysical Research Communications 208 555-561.

Bowers CY, Sartor AO, Reynolds GA \& Badger TM 1991 On the actions of the growth hormone-releasing hexapeptide, GHRP. Endocrinology 128 2027-2035.

Casanueva FF \& Dieguez C 1999 Growth hormone secretagogues: physiological role and clinical utility. Trends in Endocrinology and Metabolism 10 30-38.

Chan YY, Clifton DK \& Steiner RA 1996 Role of NPY neurones in GH-dependent feedback signalling to the brain. Hormone Research 45 12-14.

Chen C, Zhang J, Vincent JD \& Israel JM 1990 Two types of voltage-dependent calcium current in rat somatotrophs are reduced by somatostatin. Journal of Physiology 425 29-42.

Chen C, Vincent JD \& Clarke IJ 1994 Ion channels and the signal transduction pathways in the regulation of GH secretion. Trends in Endocrinology and Metabolism 5 227-233.

Chen C, Wu D \& Clarke IJ 1996 Signal transduction systems employed by synthetic GH-releasing peptides in somatotrophs. Journal of Endocrinology 148 381-386.

Cheng K, Chan WW, Barreto A Jr, Convey EM \& Smith RG 1989 The synergistic effects of His-D-Trp-Ala-Trp-D-Phe-Lys- $\mathrm{NH}_{2}$ on growth hormone $(\mathrm{GH})$-releasing factor-stimulated $\mathrm{GH}$ release and intracellular adenosine $3^{\prime}, 5^{\prime}$-monophosphate accumulation in rat primary pituitary cell culture. Endocrinology 124 2791-2798.

Cheng K, Wei L, Chaung L-Y, Chan WW-S, Butler BS, Pong SS \& Smith RG 1994 Substance P antagonist inhibits L-692,429- and GHRP-6-stimulated rat growth hormone release both in vitro and in vivo. Proceedings of the 76th Annual Meeting of the Endocrine Society, 662 (Abstract).

Cho SJ, Jeftinija K, Glavaski A, Jeftinija S, Jena BP \& Anderson LL 2002 Structure and dynamics of the fusion pores in live GH-secreting cells revealed using atomic force microscopy. Endocrinology 143 1144-1148.

Fairhhall KM, Mynett A, Thomas GB \& Robinson ICAF 1996 Central and peripheral effects of peptide and nonpeptide $\mathrm{GH}$ secretagogues on $\mathrm{GH}$ release in vivo. In Growth Hormone Secretagogues, pp 219-236. Eds BB Bercu \& RF Walker. New York: Springer.

Goth MI, Lyons CE, Canny BJ \& Thorner MO 1992 Pituitary adenylate cyclase activating polypeptide, growth hormone $(\mathrm{GH})$ releasing peptide and $\mathrm{GH}$-releasing hormone stimulate $\mathrm{GH}$ release through distinct pituitary receptors. Endocrinology 130 939-944.

Grynkiewitz G, Poenie M \& Tsien RY 1985 A new generation of $\mathrm{Ca}^{2+}$ indicators with greatly improved fluorescence properties. Journal of Biological Chemistry 260 3440-3450. 
Guillaume V, Magnan E, Cataldi M, Dutour A, Sauze N, Renard M, Razafindraibe H, Conte-Devolx B, Deghenghi R, Lenaerts V \& Oliver C 1994 Growth hormone (GH)-releasing hormone secretion is stimulated by a new GH-releasing hexapeptide in sheep. Endocrinology 135 1073-1076.

Herrington J \& Hille B 1994 Growth hormone-releasing hexapeptide elevates intracellular calcium in rat somatotropes by two mechanisms. Endocrinology 135 1100-1108.

Hickey GJ, Drisko J, Faidley T, Chang C, Anderson LL, Nicolich S, McGuire L, Rickes E, Krupa D, Feeney W, Friscino B, Cunningham P, Frazier E, Chen H, Laroque P \& Smith RG 1996 Mediation by the central nervous system is critical to the in vivo activity of the GH secretagogue L-692,585. Journal of Endocrinology 148 371-380

Howard AD, Feighner SD, Cully DF, Arena JP, Liberator PA, Rosenblum CI, Hamelin M, Hreniuk DL, Palyha OC, Anderson J, Paress PS, Diaz C, Chou M, Liu KK, McKee KK, Pong S-S, Chaung L-Y, Elbrecht A, Dashkevicz M, Heavens R, Rigby M, Sirinathsinghji DJS, Dean DC, Melillo DG, Patchett AA, Nargund R, Griffin PR, DeMartino JA, Gupta SK, Schaeffer JM, Smith RG \& Van der Ploeg LHT 1996 A receptor in pituitary and hypothalamus that functions in growth hormone release. Science $\mathbf{2 7 3}$ 974-977.

Huettner JE \& Baughman RW 1986 Primary culture of identified neurons from the visual cortex of postnatal rats. Journal of Neuroscience 6 3044-3060.

Jacks T, Hickey GJ, Judith F, Taylor J, Chen H, Krupa D, Feeney W, Schoen W, Ok D, Fisher M, Wyvratt MJ \& Smith RG 1994 Effects of acute and repeated intravenous administration of L-692,585, a novel non-peptidyl growth hormone secretagogue, on plasma growth hormone, IGF-1, ACTH, cortisol, prolactin, insulin, and thyroxine levels in beagles. Journal of Endocrinology 143 399-406.

Jeftinija S, Liu F, Jeftinija K \& Urban L 1992 Effect of capsaicin and resiniferatoxin on peptidergic neurons in cultured dorsal root ganglion. Regulatory Peptides 39 123-135.

Kojima M, Hosoda H, Date Y, Nakazato M, Matsuo H \& Kangawa K 1999 Ghrelin is a growth-hormone-releasing acylated peptide from stomach. Nature 402 656-660.

Lindstrom P \& Savendahl L 1996 Enrichment of type I and type II rat somatotrophs: characterization of growth hormone secretion in vitro. Endocrinology 137 4174-4180.

Lussier BT, French MB, Moor BC \& Kraicer J 1991a Free intracellular $\mathrm{Ca}^{2+}$ concentration and growth hormone $(\mathrm{GH})$ release from purified rat somatotrophs. III. Mechanism of action of GH-releasing factor and somatostatin. Endocrinology 128 592-603.

Lussier BT, Wood DA, French MB, Moor BC \& Kraicer J $1991 b$ Free intracellular $\mathrm{Ca}^{2+}$ concentration $\left(\left[\mathrm{Ca}^{2+}\right]_{\mathrm{i}}\right)$ and growth hormone release from purified rat somatotrophs. II. Somatostatin lowers $\left[\mathrm{Ca}^{2+}\right]_{\mathrm{i}}$ by inhibiting $\mathrm{Ca}^{2+}$ influx. Endocrinology 128 583-591.

Mau SE, Witt MR, Bjerrum OJ, Saermark T \& Vilhardt H 1995 Growth hormone releasing hexapeptide (GHRP-6) activates the inositol $(1,4,5)$-trisphosphate/diacylglycerol pathway in rat anterior pituitary cells. Journal of Receptor and Signal Transduction Research $\mathbf{1 5}$ 311-323.
Mitani M, Kaji H, Abe H \& Chihara K 1996 Growth hormone $(\mathrm{GH})$-releasing peptide and $\mathrm{GH}$ releasing hormone stimulate $\mathrm{GH}$ release from subpopulations of somatotrophs in rats. Journal of Neuroendocrinology 8 825-830.

Muller EE, Locatelli V \& Cocchi D 1999 Neuroendocrine control of growth hormone secretion. Physiological Reviews 79 511-607.

Nakazato M, Murakami N, Date Y, Kojima M, Matsuo H, Kangawa K \& Matsukura S 2001 A role for ghrelin in the central regulation of feeding. Nature 409 194-198.

Niimi M, Sato M, Wada Y, Tamaki M, Takahara J \& Kawanishi K 1994 Analysis of growth hormone release from rat anterior pituitary cells by reverse hemolytic plaque assay: influence of interleukin-1. Life Science 55 1807-1813.

Parpura V, Basarski T, Liu F, Jeftinija K, Jeftinija S \& Haydon P 1994 Glutamate-mediated glia-neuron signaling. Nature 369 744-747.

Ramirez JL, Castano JP, Torronteras R, Martinez-Fuentes AJ, Frawley LS, Garcia-Navarro S \& Gracia-Navarro F 1999 Growth hormone $(\mathrm{GH})$-releasing factor differentially activates cyclic adenosine 3',5'-monophosphate- and inositol phosphate-dependent pathways to stimulate GH release in two porcine somatotrope subpopulations. Endocrinology 140 1752-1759.

Schoen WR, Ok D, DeVita RJ, Pisano JM, Hodges P, Cheng K, Chan WW-S, Butler BS, Smith RG, Wyvratt MJ \& Fisher MH 1994 Structure activity relationships in the amino acid sidechain of L-692,429. Bioorganic and Medicinal Chemistry Letters 4 1117-1122.

Smith RG, Cheng K, Schoen WR, Pong S-S, Hickey G, Jacks T, Butler BS, Chan WW-S, Chaung L-YP, Judith F, Taylor J, Wyvratt MJ \& Fisher MH 1993 A nonpeptidyl growth hormone secretagogue. Science 260 1640-1643.

Smith RG, Van der Ploeg LHT, Howard AD, Feighner SD, Cheng K, Hickey GJ, Wyvratt MJ, Fisher MH, Nargund RP \& Patchett AA 1997 Peptidomimetic regulation of growth hormone secretion. Endocrine Reviews 18 621-645.

Smith RJ, Sam LM, Justed JM, Bundy GL, Bala GA \& Bleasdale JE 1990 Receptor-coupled signal transduction in human polymorphonuclear neutrophils: effects of a novel inhibitor of phospholipase C-dependent processes on cell responsiveness. Journal of Pharmacology and Experimental Therapeutics 253 688-697.

Tamaoki J, Chiyotani A, Takeyama K, Yamauchi F, Tagaya E \& Konno K 1993 Relaxation and inhibition of contractile response to electrical field stimulation by Beraprost sodium in canine airway smooth muscle. Prostaglandins 45 363-373.

Taylor MJ \& Clark CL 1994 Plaque assay analysis of single-cell secretion. Neuroprotocols 5 175-187.

Wu D, Chen C, Zhang J, Bowers CY \& Clarke IJ 1996 The effects of GH-releasing peptide-6 (GHRP-6) and GHRP-2 on intracellular adenosine $3^{\prime}, 5^{\prime}$-monophosphate (cAMP) levels and $\mathrm{GH}$ secretion in ovine and rat somatotrophs. Journal of Endocrinology 148 197-205.

Received in final form 20 August 2002

Accepted 4 September 2002 